\title{
Editorial
}

\section{Are President Clinton's Tax Proposals European Inspired?}

\author{
Yann Kergall, Coopers \& Lybrand, CLC Juridique et Fiscal, Paris
}

Just when the United States is vehemently opposing any form of subsidy and economic protectionism being practiced by European States at the GATT negotiations, it is interesting and perhaps even paradoxical to see that the incoming Clinton presidency tax proposals may very well be European and more particularly French inspired.

In fact, the tax reforms envisaged show an intent to exercise considerable federal control which up until now has been rather unusual on the other side of the Atlantic. This is evidenced in particular by the proposed tax incentives for American businesses and individuals coupled with increased taxation of foreign or multinational corporations involving closer scrutiny and tighter rules.

During the Presidential campaign battle, the Democrats singled out foreign corporations doing business in the United States for the single largest proposed corporate tax increase. However, Clinton's tax program also aims at US firms which offer an even more attractive source of taxable income than foreign enterprises alone. The Clinton proposals thus appear to be motivated by the objective of encouraging investment in the United States while simultaneously discouraging expatriation of funds abroad. In terms of actual tax legislation, this would mean granting of incentives to American groups so that they repatriate or at least no longer expatriate taxable income.

In this respect, transfer pricing is likely to be affected by the enforcement envisaged. This comes as no surprise given the fact that the US Congress has already taken measures to eliminate the possibilities of advantageously manipulating the law through transfer pricing practices, by granting the IRS ever-greater powers of investigation. Another implication is that certain tax benefits to businesses which move operations outside the United States, particularly to low-tax jurisdictions, would be seriously curbed. Besides the elimination of tax breaks, major business tax incentives include a targeted investment tax credit (ITC) for investment in new plants.

In addition to the above measures, the Clinton program provides for a host of measures, some of which seem inspired from the tax legislation in force in certain European countries. For instance, Clinton is proposing the creation of tax-favored enterprise zones. For a country viewed as an opponent in the current round of GATT negotiations, its new President's ideas on zoning measures certainly resemble those already practiced in European countries such as France, Great Britain, Ireland, Italy and Portugal.

Indeed, French tax provisions include a ten year ${ }^{1}$ or eight year corporate tax exemption, under certain conditions and for certain zones, as well as, for enterprises creating more than ten jobs in certain business zones, a tax representing 22 per cent of industrial investments made and offsettable against corporate income tax payable over the first ten financial years. ${ }^{2}$

Clinton also wishes to see businesses in a position to immediately deduct certain start-up expenses. In France, businesses are allowed the possibility of opting for either the immediate deduction of their start-up expenses or depreciation of said expenses over a maximum period of five years.

Further Clinton program initiatives, which may appear innovative in the United States but quite familiar to European employees, involve requiring employers to spend 1.5 per cent of their payroll on employee training or making a contribution to a national training fund. In France, all employers are required to contribute to job training at rates ranging from 0.15 per cent to 1.5 per cent of their payroll depending on the number of employees. Contributions

\footnotetext{
1 Until 1992.

${ }^{2}$ French Finance Amendment Draft for 1992.
} 
are paid into a government approved collection agency subject to the deduction of certain training expenses which can represent tax cuts.

Vice-President Gore plans to introduce legislation that would provide tax incentives for waste recycling and use of alternative fuels. Here as well, the example set by France could be called inspirational since businesses are entitled to depreciate the cost price of certain energy saving equipment items over twelve months. This is equally applicable to installations designed to process industrial waste water or to facilities for clean air. For certain electric cars, exceptional depreciation over a twelve-month period equally applies.

Where private individual taxpayers are concerned, the Clinton proposals centering around his 'fairness issues' as advanced during his campaign can be characterized by an attempt to institute greater tax equality. In practical terms, this means tax relief for wage earners in the lower and middle income family categories. Although families with a certain level of adjusted gross income would see their marginal tax rate rise from a nominal rate of 31 per cent to 36 per cent, working families with children could benefit from a tax relief which approaches the French provision that families with school age child dependents benefit from a tax cut. ${ }^{3}$ The Clinton program also provides for an expansion of the earned income tax credit, a system similar to that presently in effect in the United Kingdom.

The incoming President also proposed encouraging savings in the form of new 'individual development accounts' to help those taxpayers in the low income categories save for education, home ownership or other select purposes. In France, interest collected by virtue of home ownership savings accounts is exempted from income tax and certain taxpayers saving for the building of social housing can still benefit from a tax deduction corresponding to their savings effort.

Another facet of the 'fairness' program is the proposed measures to increase taxation of top income with a higher top tax rate and a 10 per cent 'millionaire's surtax' which would also apply to capital gains taxes, while cutting back on deductions and phasing out personal exemption possibilities for this sector of the taxpayer population. In addition, at corporate levels, the corporate tax deduction for top executive pay would be limited to $\$ 1$ million per year. This measure would come close to the provisions presently in effect in France which aim to limit the deductibility of excessive compensation paid to top executives.

Normally, no reduction in capital gains tax is planned. Even without this, however, the planned increase of the top personal rate would create a wider differential between the top ordinary income tax rate and the capital gains rate of 28 per cent, representing a spread in the range of eight points for private individuals. This would remain even when the effects of the itemized deduction cutback and the personal exemption phaseout are added into the equation. This differential exists in France as in most countries where the maximum rate of income tax is significant.

A detailed study of the existing tax legislation in other European States would show further analogies with Clinton's tax program. However, on certain issues, Clintons' program evidences considerable creativity.

As an example, he has proposed a targeted capital gains tax relief to encourage investment whether at the level of private individuals or corporate entities, representing a 50 per cent exclusion of gain from long-term investments in new business. He would also provide a 100 per cent tax exclusion for new, direct long-term investments (defined as ten years or more) in the stock of small businesses with $\$ 5$ million or less in paid-in capital.

To face the problem of rising costs of medication in the United States, the Clinton program provides for the elimination of tax advantages previously offered to drug companies, and for a cut in tax credits granted to pharmaceutical companies which practice price increases at rates 'faster than Americans' incomes rise'. Other measures could be taken to discourage these same companies for spending more on advertizing than they do on research and development of new products. The latter measures also indicate a move toward greater government control through taxation for the purpose of compensating the loopholes in the American health care system.

As a final remark and a sign of the times, the elimination of tax deductions for lobbying expenses clearly differentiates the incoming Clinton administration from that of its predecessor.

The new President is surrounded by a reputed team of expert professionals who have not thought twice about looking towards the tax legislation presently in effect in Europe for their inspiration and aspiration to greater social justice and economic control as promised by the Democratic campaign.

\footnotetext{
${ }^{3}$ French Finance Bill fồ 1993.
} 